\title{
Biological Risk in Nursing Care Provided in Family Health Units
}

\author{
Ana Carla Moreira Cardoso ${ }^{1}$ \\ Rosely Moralez de Figueiredo ${ }^{2}$
}

There is very frequent exposure to potentially contaminated material in procedures performed by nursing professionals. This exploratory and descriptive study characterizes the potential risk of biological exposure in procedures performed by nursing professionals in ten Family Health units in São Carlos-SP, Brazil. We observed 238 procedures involving potential risk of contact with biological material, in which more than $90 \%$ involved the use of needles. The average rates of adherence to standard precautions were: $27.9 \%$ hand washing prior to procedures; $41.4 \%$ use of gloves; and $88.8 \%$ adequate disposal of piercing and cutting instruments. These professionals are subject to risks similar to those which hospital workers are also subjected, because they have a high risk of blood exposure and the frequency with which they handle needles is very high.

Descriptors: Nursing; Occupation Risks; Exposure to Biological Agents.

Universidade Federal de São Carlos, Departamento de Enfermagem, Brazil:

${ }^{1}$ Nursing Undergraduate Student. Scholarship holder PIBIC/CNPq. E-mail: anaacarla2006@yahoo.com.br.

2 RN, Adjunct Professor. E-mail: rosely@ufscar.br.

Corresponding Author:

Rosely Moralez de Figueiredo

Universidade Federal de São Carlos. Departamento de Enfermagem

Rod. Washington Luís, Km 235

CEP 13565-905 São Carlos, SP, Brasil

E-mail: rosely@ufscar.br 


\title{
Situações de risco biológico presentes na assistência de enfermagem nas unidades de saúde da família (USF)
}

Exposição a material potencialmente contaminado é frequente nas atividades do profissional de enfermagem. Este estudo, de caráter exploratório descritivo de abordagem quantitativa, teve como objetivo caracterizar os riscos potenciais de exposição biológica nas ações desenvolvidas pelos profissionais de enfermagem em dez USFs do município de São Carlos, SP. Foram observados 238 procedimentos com possível risco de contato com material biológico, sendo que mais de $90 \%$ desses envolviam o uso de agulhas. A taxa média geral de adesão às precauções padrão foi de $27,9 \%$ na lavagem de mãos prévia ao procedimento, $41,4 \%$ no uso de luvas e de $88,8 \%$ no descarte adequado de material perfurocortante. Conclui-se que esses profissionais estão sujeitos a riscos semelhantes aos encontrados na área hospitalar, uma vez que também manipulam agulhas com muita frequência e possuem alto risco de exposição a sangue.

Descritores: Enfermagem; Riscos Ocupacionais; Exposição a Agentes Biológicos.

\section{Situaciones de riesgo biológico presentes en la asistencia de enfermería en las unidades de salud de la familia (USF)}

\begin{abstract}
La exposición a material potencialmente contaminado es frecuente en las actividades del profesional de enfermería. Este estudio, de carácter exploratorio y descriptivo con abordaje cuantitativo, tuvo como objetivo caracterizar los riesgos potenciales de exposición biológica en las acciones desarrolladas por los profesionales de enfermería en diez USFs del municipio de Sao Carlos, SP. Fueron observados 238 procedimientos con posible riesgo de contacto con material biológico, siendo que más de $90 \%$ de estos envolvían el uso de agujas. Previo al procedimiento, la tasa promedio general de adhesión a las precauciones estándar fue de $27,9 \%$ en el lavado de manos, $41,4 \%$ en el uso de guantes y de $88,8 \%$ en el descarte adecuado de material punzo cortante. Se concluye que esos profesionales están sujetos a riesgos semejantes a los encontrados en el área hospitalaria, una vez que también manipulan agujas con mucha frecuencia y poseen alto riesgo de exposición la sangre.
\end{abstract}

Descriptores: Enfermería; Riesgos Laborales; Exposición a Agentes Biológicos.

\section{Introduction}

Needlestick and sharp instrument accidents among nursing workers are frequent, especially due to the recurrent use of needles in their professional practice. One study carried out in three Brazilian hospitals notes that $68.5 \%$ of the reported occupational accidents among health professionals refer to needlestick and other sharp-related injuries. These accidents expose these professionals to the risk of infections, especially Hepatitis $\mathrm{B}$ and $\mathrm{C}$ and the Acquired Human Immunodeficiency virus (HIV) $)^{(1-2)}$.

A series of actions are recommended for any modality of health care service to minimize the risk of occupational exposure inherent to the practice. The main one is the adoption of Standard Precautions (SP). These precautions include measures to carefully manipulate piercing and cutting instruments, to discard them in appropriate places, not to recap needles, and use gloves and goggles whenever there is risk of contact with blood or other biological material. Educating and training teams, reviewing techniques and acquiring safer devices and environments are other recommended measures $^{(1,3-5)}$.

The risks of exposure to biological material to which health professionals are subject during care delivery in 
the hospital setting are well known and well measured(6). However, there is a scarcity of studies addressing this subject in extra-hospital settings ${ }^{(7-9)}$, especially in Family Health Program (FHP) units.

In Brazil, the FHP is a strategy that proposes a new way of delivering care and consequently will change the current work process. Characterizing the health actions carried out in this new scenario and identifying the risk of biological exposure to which professionals are subject is extremely important both to advance knowledge of the subject and also to support actions aimed to minimize risks.

There are currently about 29,000 Family Health teams spread out in more than 5,000 cities that cover $49.5 \%$ of the Brazilian population, which corresponds to about 93.9 million of people(10).

Considering only the required minimum number for each team, one nurse and one nursing auxiliary according to the Ministry of Health, there are 58,000 nursing professionals spread over the Brazilian territory who might be exposed to, so far, unmeasured biological risks.

This study identifies the situations where there is risk of biological exposure for nursing professionals during nursing care delivered in units of the FHP.

\section{Method}

This exploratory, prospective study with a quantitative approach was carried out in the FHP units in São Carlos, SP, Brazil from November 2007 to May 2008, where nursing procedures involving biological risk were observed. These procedures were recorded in a script developed by the authors that identified whether standard precautions were being adopted such as hand washing, use of gloves and protective devices, and disposal of piercing/cutting instruments.

The study complied with the Resolution 196/96, which regulates research involving human subjects and was approved by the Ethics in Human Research Committee at the Federal University of São Carlos (UFSCar).

\section{Results}

Ten units of the 12 FHP units existent in the city were visited 50 times, totaling 200 hours of observation (five shifts of four hours in each unit). A total of 238 procedures involving biological exposure undertaken by 11 nurses and 19 nursing auxiliaries were observed and are distributed as follows: $42.4 \%$ blood sample collection, $13.9 \%$ capillary blood glucose, $27.7 \%$ intramuscular (IM) and subcutaneous (SC) medications, $6.3 \%$ intravenous (IV) medication and $9.7 \%$ dressings. No accident involving biological risk was recorded during the study period.

The vacuum blood collection system was used in only $19.6 \%$ of the observed 101 blood sample collections; syringe and needle were used and blood was then transferred to the test tube in the remaining cases. Gloves were used in $74.3 \%$ of punctures, however, they were not changed between procedures of one patient and the next. Hands were not washed prior to a procedure in $92.1 \%$ of the cases and disposal of piercing/cutting instruments was considered appropriate in $99 \%$ of cases (Table 1).

Table 1 - Adherence of the nursing teams in the studied FHP units to hand washing and glove use, and disposal of piercing/cutting instruments during procedures involving biological exposure. São Carlos, SP, Brazil 2008

\begin{tabular}{|c|c|c|c|c|c|c|c|c|c|c|c|c|}
\hline & \multicolumn{4}{|c|}{ Prior hand washing } & \multicolumn{4}{|c|}{ Gloves } & \multicolumn{4}{|c|}{$\begin{array}{l}\text { Appropriate disposal of piercing } \\
\text { cutting instruments }\end{array}$} \\
\hline & \multicolumn{2}{|c|}{ Yes } & \multicolumn{2}{|c|}{ No } & \multicolumn{2}{|c|}{ Yes } & \multicolumn{2}{|c|}{ No } & \multicolumn{2}{|c|}{ Yes } & \multicolumn{2}{|c|}{ No } \\
\hline & $\mathbf{N}$ & $\%$ & $\mathbf{N}$ & $\%$ & $\mathbf{N}$ & $\%$ & $\mathbf{N}$ & $\%$ & $\mathbf{N}$ & $\%$ & $\mathbf{N}$ & $\%$ \\
\hline Blood sample collection & 8 & 7.9 & 93 & 92.1 & 75 & 74.3 & 26 & 25.7 & 100 & 99 & 1 & 1 \\
\hline IM and SC medications & 41 & 62.1 & 25 & 37.9 & - & - & - & - & 56 & 84.8 & 10 & 15.2 \\
\hline IV medications & 8 & 53.3 & 7 & 46.7 & 4 & 26.7 & 11 & 73.3 & 11 & 73.3 & 4 & 26.7 \\
\hline Capillary blood glucose & 3 & 9 & 30 & 91 & 10 & 30.3 & 23 & 69.7 & 22 & 66.7 & 11 & 33.3 \\
\hline Dressings & 5 & 21.3 & 18 & 78.3 & 23 & 100 & - & - & - & - & - & - \\
\hline Total & 65 & 27.3 & 173 & 72.7 & 112 & 65.1 & 60 & 34.9 & 189 & 87.9 & 26 & 12.1 \\
\hline
\end{tabular}


The following adherence rates were found during the administration of IV medication: $26.7 \%$ used gloves, $53.3 \%$ washed hands prior to the procedure and $27.3 \%$ washed hands after the procedure.

One risk situation was observed in which professionals tried to puncture a vein of a very agitated child. Several punctures, with change of devices and involving various professionals, were performed.

A manual lancet was used $100 \%$ of the times to measure capillary blood glucose. Disposal was considered appropriate in $66.7 \%$ of the cases, gloves were used only $30.3 \%$ of the time, and hands were washed $9 \%$ of the time before the procedure and $20 \%$ of time after it.

IM and SC medication procedures, including vaccination, were also observed in which hand washing prior to a procedure was performed in $62.1 \%$ of the cases and in $52.5 \%$ of the cases professionals washed their hands after the procedure. Appropriate disposal of piercing/cutting instruments occurred in $84.8 \%$ of the cases.

The average rates of adherence to SP during procedures involving needles were: $27.9 \%$ hand washing prior to the procedure, $41.4 \%$ used gloves, and $88.8 \%$ appropriately disposed of piercing and cutting instruments.

\section{Discussion}

According to the literature, the high number of occupational accidents among nursing workers caused by percutaneous exposure is related to the frequent handling of needles(1). These data indicate these are high-risk procedures for the transmission of blood borne pathogens since they involve devices used for intravascular access, lumen needles and blood exposure ${ }^{(9,11)}$, and account for more than $80 \%$ of infectious diseases transmission among health workers ${ }^{(12)}$.

We note that transferring blood from the syringe to the test tube and thus handling already used needles greatly increases the risk of exposure, which violates internationally recommended safety standards and standard precautions ${ }^{(1,13)}$. Handling bare needles and actively recapping them accounted for $16 \%$ of accidents with piercing or cutting instruments reported among health professionals working in the public system ${ }^{(9)}$.

Devices such as the vacuum blood collection system, where there is no transference of tubes, and needles have safety devices, are strongly recommended to diminish the risks of percutaneous exposure ${ }^{(9,11)}$. So far, the use of these needles is not prevalent in the majority of Brazilian healthcare settings and the high $\operatorname{cost}^{(9)}$ is the main impediment to their use. Nonetheless, $43 \%$ of nurses interviewed in an American study reported percutaneous exposure even with the use of "safe devices" for vascular access(7), which reinforces the importance of constant training and supervision when implementing a new device, even if it is safer than the previous ones.

Situations involving agitated patients, including children, are acknowledged factors of exposure risk. Studies carried out in the hospital setting indicate the high coefficient of risk for percutaneous exposure in pediatric units where workers provide care to children who usually become agitated and resist procedures, especially during the most painful ones such as venipuncture, dressings and sample collection for exams ${ }^{(14)}$.

Appropriate disposal of piercing and cutting instruments was mostly observed after capillary blood glucose collection. This might be explained by the fact that this procedure is carried out in different places in the unit, including waiting rooms and corridors, in which the lancet is transported to the disposal site afterwards. The literature indicates that the accidental collision between professionals working in public health units is the main cause of $3.22 \%$ of accidents with piercing and cutting instruments among professionals due to the inappropriate ${ }^{(9)}$ transportation of this material. Discarding needles in overcrowded places and transporting or manipulating unprotected needles accounted for $40.3 \%$ of studied accidents ${ }^{(13)}$

In this study, more than $90 \%$ of the procedures with a potential risk for biological exposure involved the use of needles and blood exposure, data that corroborate the findings of studies carried out both in hospital settings ${ }^{(7,11)}$ and in the public health service ${ }^{(9)}$, where the adoption of SP is the main control measure used(12).

The low adherence of health professionals to SP has been extensively reported $(4,15)$ in addition to evidence showing that SP diminishes blood exposure risks ${ }^{(12)}$. Data from the Brazilian literature, where adherence rates during venipuncture performed in hospital settings is assessed, show similar figures while hand washing prior to procedures and use of gloves occurred in only $15.6 \%$ of cases and appropriate disposal of piercing/ cutting instruments occurred in $65.1 \%$ of observed punctures ${ }^{(15)}$

It is worth noting that the adoption of recommended measures is not only designed for the protection of professionals. The ultimate goal of SP is to reduce morbidity, limit contact with secretions, bodily liquids, 
skin lesions and blood both for health professionals and patients $^{(1,16)}$.

Data obtained in this study corroborate data from Brazilian studies addressing the risk of biological exposure in different health facilities ${ }^{(2,5,9)}$. However, we infer that specificities of each studied setting deserve special attention. Variables such as the facility's physical area, number of patients cared for, epidemiological characteristics of the local population, profile of the health team and even the organization of the city health network should be taken into account when assessing the potential risk of biological exposure in procedures performed in FHS units.

\section{Conclusion}

We concluded that nursing professionals working in units of the FHS in São Carlos, SP, Brazil are exposed to biological material, especially regarding percutaneous exposure and blood contact exposure, since the frequency with which they handle needles is very high.

No accidents with biological risk occurred during the study period, although risk situations were identified in $80.4 \%$ of blood sample collections, in $33.3 \%$ of disposals of capillary blood glucose lancet, in addition to low adherence to hand washing and the use of gloves, especially during the capillary blood glucose measurement and administration of IV medication.

In general, adherence to SP varied according to the procedure and necessary precaution. The fact that patients are not hospitalized seemed not to interfere, since the rates of adherence to precautions are similar to those found in studies addressing hospital settings.

Although these results provide a picture of only one city, they do provide important support for improving knowledge about the assessment of biological risk present in extra-hospital nursing care, especially in FHP units. We believe this field of knowledge still has many gaps, which warrant further research.

\section{References}

1. Marziale MHP, Nishimura KYN, Ferreira MM. Riscos de contaminação ocasionados por acidentes de trabalho com material pérfuro-cortante entre trabalhadores de enfermagem. Rev. LatinoAm. Enfermagem 2004 janeiro-fevereiro; 12(1):36-42.

2. Monteiro CM, Benatti MCC, Rodrigues RCM. Occupational accidents and health-related quality of life: a study in three hospitals. Rev. Latino-Am. Enfermagem. 2009 janeiro-fevereiro; 17(1):101-7.

3. Rapparini C, Saraceni V, Lauria LM Barroso BF, Vellozo V, Cruz $M$, et al. Occupational exposures to bloodborne pathogens among healthcare workers in Rio de Janeiro, Brazil. J Hosp Infect 2007 February; 65(2):131-7.

4. Doebbeling BN, Vaughn TE, McCoy KD, Beekmann SE, Woolson RF, Fergunson KJ, et al. Percutaneous injury, blood exposure, and adherence to standard precautions: are hospitalbased health care providers still at risk? Clin Infect Dis 2003; 37(8):1006-13.

5. Canini SRMS, Moraes SA, Gir E, Freitas ICM. Percutaneous injuries correlates in the nursing team of a Brazilian tertiarycare university hospital. Rev. Latino-Am. Enfermagem. 2008 outubro; 16(5):818-23.

6. Figueiredo RM, Resende MR, Garcia MT, Sinkoc VM, Campos EM, Papaiordanou PMO. Aderência à profilaxia com antiretroviral pós-exposição por profissionais de saúde e vítimas de violência sexual. Rev Ciênc Méd 2005 setembro-outubro; 14(5):399-403.

7. Gershon RRM, Qureshi KA, Pogorzelska M, Rosen J, Gebbie KM, Brandt-Rauf PW, et al. Non-hospital based registered nurses and the risk of bloodborne pathogen exposure. Ind Health 2007 November; 45(5):695-704.
8. Gershon RR, Pogorzelska M, Qureshi KA, Sherman M. Home health care registered nurses and the risk of percutaneous injuries: a pilot study. Am J Infect Control 2008 April; 36(3):165-72.

9. Chiodi MB, Marziale MHP, Robazzi MLCC. Occupational accidents involving biological material among public health workers. Rev. Latino-Am. Enfermagem. 2007 julho-agosto; 15(4):632-8.

10. Ministério da Saúde (BR). [homepage na internet] Brasília: Ministério da Saúde; [Acessado 07 abril 2009]. Programa Saúde da Família. Disponível em: http://dtr2004.saude.gov.br/dab/ atencaobasica.php.

11. Marziale MHP, Rodrigues CM. The scientific production on occupational accidents with needlestick materials among members of the nursing team. Rev. Latino-Am. Enfermagem. 2002 julho; 10(4):571-7.

12. Fergunson KJ, Waitzkin H, Beekmann SE, Doedbbling BN. Critical incidents of nonadherence with standard precautions guidelines among community hospital-based health care workers. J Gen Intern Med 2004 July; 19(7):726-31.

13. Brevidelli MM, Cianciarullo TI. Análise dos acidentes com agulhas em um hospital universitário: situações de ocorrência e tendências. Rev. Latino-Am. Enfermagem. 2002 novembrodezembro; 10(6):780-6.

14. Ribeiro EJG, Shimizu HE. Acidentes de trabalho com trabalhadores de enfermagem. Rev Bras Enferm 2007 setembrooutubro; 60(5):535-40.

15. Cirelli MA, Figueiredo RM, Zem-Mascarenhas SH. Adherence to standard precaution in the peripheral vascular access. Rev. Latino-Am. Enfermagem. 2007 junho, 15(3):512-4.

16. Sridhar MR, Boopathi S, Lodha R, Kabra SK. Standard precautions and post exposure prophylaxis for preventing infections. Indian J Pediatr 2004 July; 71(7):617-26. 